PII S0271-5198(96)00056-0

\title{
CALL
}

The Expert Panel for Standardisation in Hemorheological Laboratory Techniques with special reference to Red Cell Rheology wants to set up a survey of

\section{COMMERCIALLY AVAILABLE HEMORHEOLOGICAL LABORATORY INSTRUMENTS}

Colleagues involved in the development and/or manufacturing of such instruments are invited to supply the Expert Panel with the following information:

1. name of instrument and application field.

2. name, address, tel. fax, e-mail of manufacturer.

3. detailed description of the technique

e.g. brochure (if available), key references, prize indication.

4. User list (if available)

5. Availability of a demonstration model and willingness to co-operate in case a comparative workshop is organized.

Please, send information to:

dr. Max R. Hardeman

Lab. for Clinicail Hemorheology,

Dept. of Internal Medicine, Academic Medical Center,

Meibergdreef 9, $1105 \mathrm{AZ}$ Amsterdam, the Netherlands.

Tel. nr. +31 20 5663824; Fax 6972286

E-mail: M.R.Hardeman@amc.uva.nl 